\title{
Influence of Different Mulch Materials on Vegetative Growth and Yield of Ginger (Zingiber officinale Rosc.) under Drip Irrigation System
}

\author{
Mukul Kumar, Swapnil Dubey, P.K. Dwivedi, A.K. Yadav and Mohit Kumar* \\ Krishi Vigayn Kendra, Raisen, Madhya Pradesh, India \\ *Corresponding author
}

\author{
A B S T R A C T
}

\begin{tabular}{|c|}
\hline $\begin{array}{l}\text { K e y w o r d s } \\
\text { Ginger, Drip } \\
\text { irrigation, } \\
\text { Mulching, Yield }\end{array}$ \\
\hline Article Info \\
\hline $\begin{array}{l}\text { Accepted: } \\
\text { 24 January } 2018 \\
\text { Available Online: } \\
\text { 10 February } 2018\end{array}$ \\
\hline
\end{tabular}

A field trial was conducted at the Krishi Vigyan Kendra, Raisen, Madhya Pradesh for two consecutive years during 2016-2017 \& 2017-2018 to determine the influence of different mulch materials on vegetative growth and yield of ginger (Zingiber officinale Rosc.) under drip irrigation system. The research trials for the consecutive two years showed that plastic mulch resulted significantly higher in plant height, No. of tillers clump ${ }^{-1}$, Number of leaves clump $^{-1}$, No. of primary rhizomes, Length of primary rhizome $(\mathrm{cm})$, Diameter of primary rhizome $(\mathrm{cm})$, Number of secondary rhizome, Length of secondary rhizome $(\mathrm{cm})$, Diameter of secondary rhizome $(\mathrm{cm})$, Rhizome yield plant ${ }^{-1}(\mathrm{~g})$ and Rhizome yield $(\mathrm{t})$ $\mathrm{ha}^{-1}$, whereas days to maturity were lower in the treatment of control. The highest yield plant $^{-1}$ and ha ${ }^{-1}$ was observed under the treatment of plastic mulch (434.13 gm plant ${ }^{-1}$ and $34.730 \mathrm{t} \mathrm{ha}^{-1}$ ) with $124.20 \%$ increase in yield as compared to control without mulch (193.80 gm plant ${ }^{-1}$ and $15.49 \mathrm{t} \mathrm{ha}^{-1}$ ). Followed by yield plant ${ }^{-1}$ and yield ha ${ }^{-1}$ were observed under the treatment of Butea monosperma and Paddy straw almost at par for both treatment (293.53 gm plant ${ }^{-1}, 23.480 \mathrm{t} \mathrm{ha}^{-1}$ and 272.617 gm plant $^{-1}, 21.807 \mathrm{t} \mathrm{ha}^{-1}$, respectively).

\section{Introduction}

Ginger is a high value cash crop and requires lot of management practices for increasing its production and productivity. Mulching the fields with green manure is the most important operations carried out for successful ginger production. In the dry months, it conserves the moisture in the soil and enhances soil temperature for proper germination of the rhizome. In addition, it checks weed growth and enriches the fertility of the soil after decomposition of the weeds. Further it prevents washing out of soil and nutrients during heavy rains (Randhawa, 1969 and
Mohanty, 1977). Mulching has been found to increase the yield of ginger (Aclan, 1976 and Mohanty and Sharma, 1978). Ginger being a crop with high water requirement, assured water supply throughout its growth period of 8 to 9 months is essential. Increasing scarcity of water often encountered in many parts of Madhya Pradesh regions necessitates alternative means to provide adequate water to the crop without wastage. Irrigation plays a paramount role in increasing the use of inputs and enhancing cropping intensity as well as productivity of a crop. However, water is becoming increasingly scare worldwide due to various reasons. Drip irrigation is an irrigation 
technique which saves water and fertilizer by allowing water to drip slowly to the roots of plants, either onto the soil surface or directly onto the root zone. Farmers look towards the Ginger crop as a cash crop with drip irrigation technique, now a day's inline drip tubes used instead of online dripper from last few years. Hence, the present study was taken up in ginger cv. Suprabha with the objective of studying the impact of different mulch materials on vegetative growth and yield of ginger under drip irrigation system.

\section{Materials and Methods}

The field experiments were conducted at Krishi Vigyan Kendra, Raisen, Madhya Pradesh during 2016-2017 \& 2017-2018 on plain land having medium black soil. Four treatments were used namely $\mathrm{T}_{1}$-silver plastic film of $50 \mu$ thickness (200 gauge), $\mathrm{T}_{2}$-green leaves of Butea monosperma, $T_{3}$ - one year old of paddy straw and $\mathrm{T}_{4}$ - control (without mulch). The drip irrigation system was installed and operated daily to provide the sufficient moisture to the plants. The lateral lines were laid parallel to the crop rows and each lateral served two rows of crop. Emitters were fixed $0.3 \mathrm{~m}$ apart to serve the irrigation water requirement of plants. Standard agronomic practices such as fertilization and plant protection measures were applied during the entire crop period. The FYM $20 \mathrm{t} \mathrm{ha}^{-1}$ was applied as basal dose and $100 \mathrm{~kg}$ each of $\mathrm{N}, \mathrm{P}$ and $\mathrm{K} \mathrm{ha}^{-1}$ was applied in split doses through drip irrigation. The experiment was conducted in a randomized block design with three replications. Ginger rhizomes were sown at a spacing of $40 \mathrm{~cm} \times 25 \mathrm{~cm}$ in the last week of April in both the years. Observations were recorded on plant height $(\mathrm{cm})$, No. of tillers/clump, Number of leaves/clump, Days to maturity, No. of primary rhizomes, Length of primary rhizome $(\mathrm{cm})$, Diameter of primary rhizome $(\mathrm{cm})$, Number of secondary rhizome, Length of secondary rhizome $(\mathrm{cm})$, Diameter of secondary rhizome (cm), Rhizome yield /plant (g) and Rhizome yield/ hectare (t). The number of sprouts were counted from each treatment at 50 DAP. Growth parameters were recorded in the first week of November. The crop was harvested in the last week of December and yield per hectare was estimated.

\section{Results and Discussion}

The experimental results shows the pooled values of both year treatment-wise observations of the crop were recorded from April 2016 to December 2017. In the Table 1, 2 and 3 shows the pooled values of both year observation highly significant value of plant height $(68.697 \mathrm{~cm})$, no. of tillers clump $^{-1}$ (16.100), no. of leaves clump ${ }^{-1}$ (136.557), no. of primary rhizomes (8.863), length of primary rhizomes $(7.237 \mathrm{~cm})$, diameter of primary rhizomes $(3.507 \mathrm{~cm})$, Number of secondary rhizome (12.387), length of secondary rhizome (4.547), diameter of secondary rhizome (3.043), rhizome yield plant $^{-1}$ and rhizome yield $\mathrm{ha}^{-1}$ (434.133 gm plant $^{-1} \& 34.730 \mathrm{t} \mathrm{ha}^{-1}$ ) under the treatment $\mathrm{T}_{1}$ as compared to the treatment of $\mathrm{T}_{4}(38.20 \mathrm{~cm}$, $6.52,55.74,4.29,3.04 \mathrm{~cm}, 1.49 \mathrm{~cm}, 4.47,1.60$ $\mathrm{cm}, 1.17 \mathrm{~cm}, 1.173 \mathrm{gm}$ plant $^{-1}$ and 15.497 tha $^{-}$ 1 , respectably). This could be due to plastic mulch have fully suppressed the weeds growth, check the soil erosion, Greater uptake of nutrients and water availability to plants and thus minimized the crop-weed competition as compared to non-mulched condition, while in case of days to maturity plastic mulch was found higher (241.620 days) as compared to without mulch (200.870 days) similar result was found (Kalyankar et al., 2011 and Reddy et al., 2017). Followed by result shows that yield was plant ${ }^{-1}(\mathrm{gm})$ and yield ha ${ }^{-1}(\mathrm{t})$ at par of both treatment $\mathrm{T}_{2}$ and $\mathrm{T}_{3}$ (293.53gm, 23.480 t and $272.61 \mathrm{gm}, 21.80 \mathrm{t}$, respectably) as compared to without mulch (1.173 gm plant ${ }^{-1}$ and $\left.15.497 \mathrm{t} \mathrm{ha}^{-1}\right)$. 
Table.1 Effect of mulch materials on growth parameter in ginger

\begin{tabular}{|l|c|c|c|c|}
\hline Treatment & $\begin{array}{l}\text { Plant height } \\
(\mathbf{c m})\end{array}$ & $\begin{array}{l}\text { No. of } \\
\text { tillers/clump }\end{array}$ & $\begin{array}{c}\text { Number of } \\
\text { leaves/clump }\end{array}$ & Days to maturity \\
\hline $\mathrm{T}_{\mathbf{1}}$ & 68.697 & 16.100 & 136.557 & 241.620 \\
\hline $\mathrm{T}_{2}$ & 50.990 & 12.577 & 92.177 & 230.923 \\
\hline $\mathrm{T}_{3}$ & 44.920 & 12.307 & 84.700 & 234.740 \\
\hline $\mathrm{T}_{4}$ & 38.200 & 6.523 & 55.747 & 200.870 \\
\hline $\mathrm{C.D.}(\mathbf{P = 0 . 0 5 )}$ & 13.864 & 2.785 & 17.679 & 4.676 \\
\hline $\mathrm{SE}(\mathbf{m})$ & 3.930 & 0.789 & 5.011 & 1.325 \\
\hline $\mathbf{S E}(\mathbf{d})$ & 5.558 & 1.116 & 7.087 & 1.874 \\
\hline C.V. & 13.425 & 11.513 & 9.405 & 1.011 \\
\hline
\end{tabular}

Table.2 Effect of mulch materials on rhizome yield parameter in ginger

\begin{tabular}{|l|c|c|c|c|}
\hline Treatment & $\begin{array}{l}\text { No. of } \\
\text { primary } \\
\text { rhizomes }\end{array}$ & $\begin{array}{l}\text { Length of } \\
\text { primary } \\
\text { rhizome }\end{array}$ & $\begin{array}{l}\text { Diameter of } \\
\text { primary rhizome }\end{array}$ & $\begin{array}{l}\text { Number of secondary } \\
\text { (cm) }\end{array}$ \\
\hline $\mathrm{T}_{\mathbf{1}}$ & 8.863 & 7.237 & 3.507 & 12.387 \\
\hline $\mathrm{T}_{2}$ & 6.487 & 5.433 & 2.527 & 8.540 \\
\hline $\mathrm{T}_{3}$ & 5.630 & 5.050 & 2.027 & 7.533 \\
\hline $\mathrm{T}_{4}$ & 4.297 & 3.043 & 1.497 & 4.477 \\
\hline $\mathbf{C . D .}(\mathbf{P}=\mathbf{0 . 0 5})$ & 2.724 & 2.307 & 1.044 & 0.517 \\
\hline $\mathbf{S E}(\mathbf{m})$ & 0.772 & 0.654 & 0.296 & 0.728 \\
\hline $\mathbf{S E}(\mathbf{d})$ & 1.092 & 0.925 & 0.419 & 10.834 \\
\hline C.V. & 21.159 & 21.817 & 21.455 & \\
\hline
\end{tabular}

Table.3 Effect of mulch materials on rhizome yield parameter in ginger

\begin{tabular}{|l|c|c|c|c|}
\hline Treatment & $\begin{array}{l}\text { Length of } \\
\text { secondary } \\
\text { rhizome }(\mathbf{c m})\end{array}$ & $\begin{array}{l}\text { Diameter of } \\
\text { secondary } \\
\text { rhizome }(\mathbf{c m})\end{array}$ & $\begin{array}{l}\text { Rhizome yield } \\
\text { /plant }(\mathbf{g})\end{array}$ & $\begin{array}{l}\text { Rhizome yield/ } \\
\text { hectare }(\mathbf{t})\end{array}$ \\
\hline $\mathrm{T}_{\mathbf{1}}$ & 4.547 & 3.043 & 434.133 & 34.730 \\
\hline $\mathrm{T}_{2}$ & 2.403 & 2.197 & 293.533 & 23.480 \\
\hline $\mathrm{T}_{3}$ & 2.143 & 1.937 & 272.617 & 21.807 \\
\hline $\mathrm{T}_{4}$ & 1.603 & 1.173 & 193.803 & 15.497 \\
\hline $\mathrm{C.D.}(\mathbf{P}=\mathbf{0 . 0 5})$ & 1.578 & $\mathrm{NS}$ & 63.944 & 5.116 \\
\hline $\mathrm{SE}(\mathbf{m})$ & 0.447 & 0.384 & 18.126 & 1.450 \\
\hline $\mathrm{SE}(\mathbf{d})$ & 0.633 & 0.543 & 25.634 & 2.051 \\
\hline $\mathbf{C . V}$. & 28.981 & 31.880 & 10.517 & 10.519 \\
\hline
\end{tabular}

$\mathrm{T}_{1}$ - Silver color plastic mulch

$\mathrm{T}_{2}$ - Green leaves of Butea monosperma

$\mathrm{T}_{3}$ - Paddy straw

$\mathrm{T}_{4}-$ Without mulch (control) 

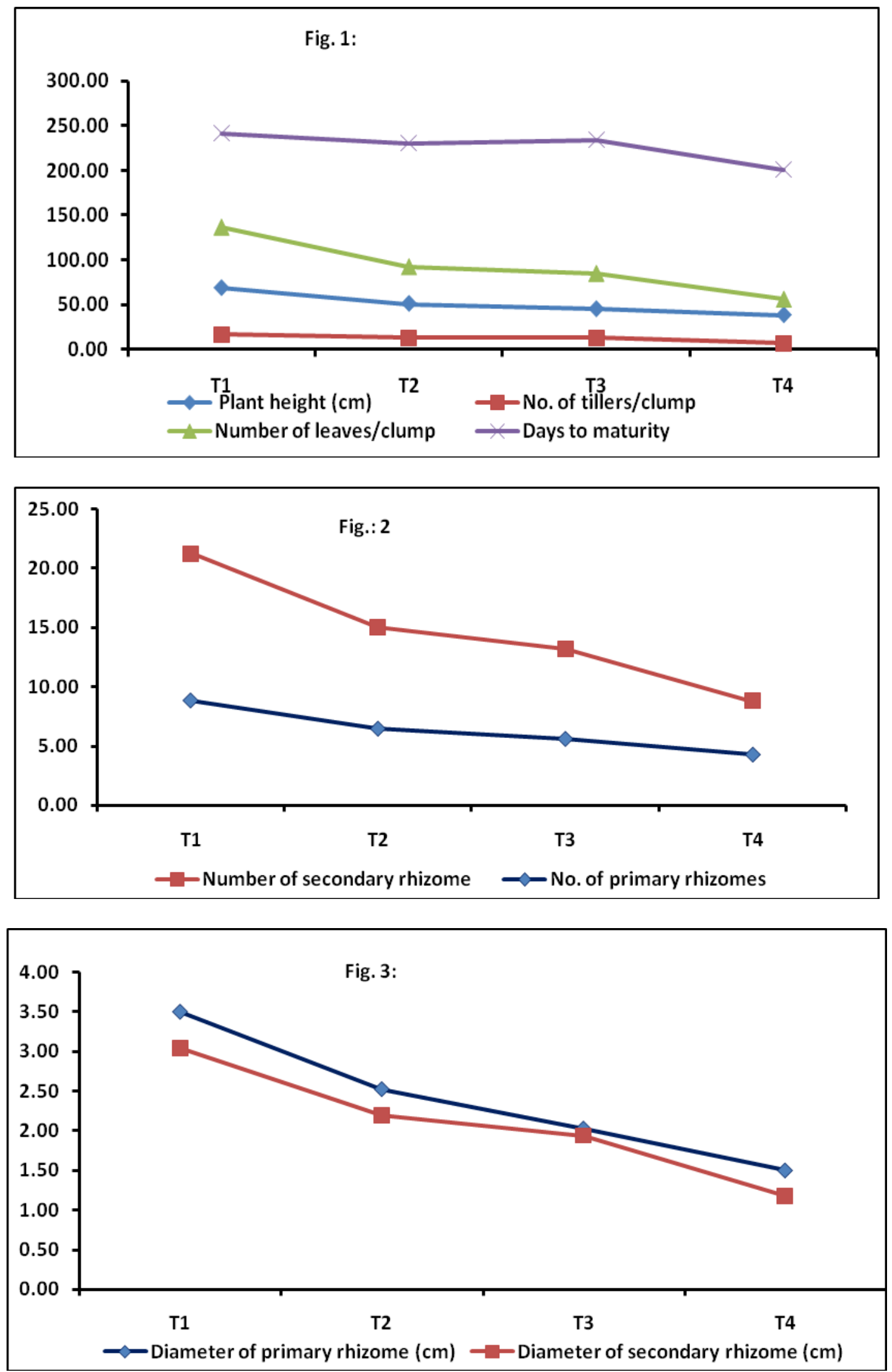

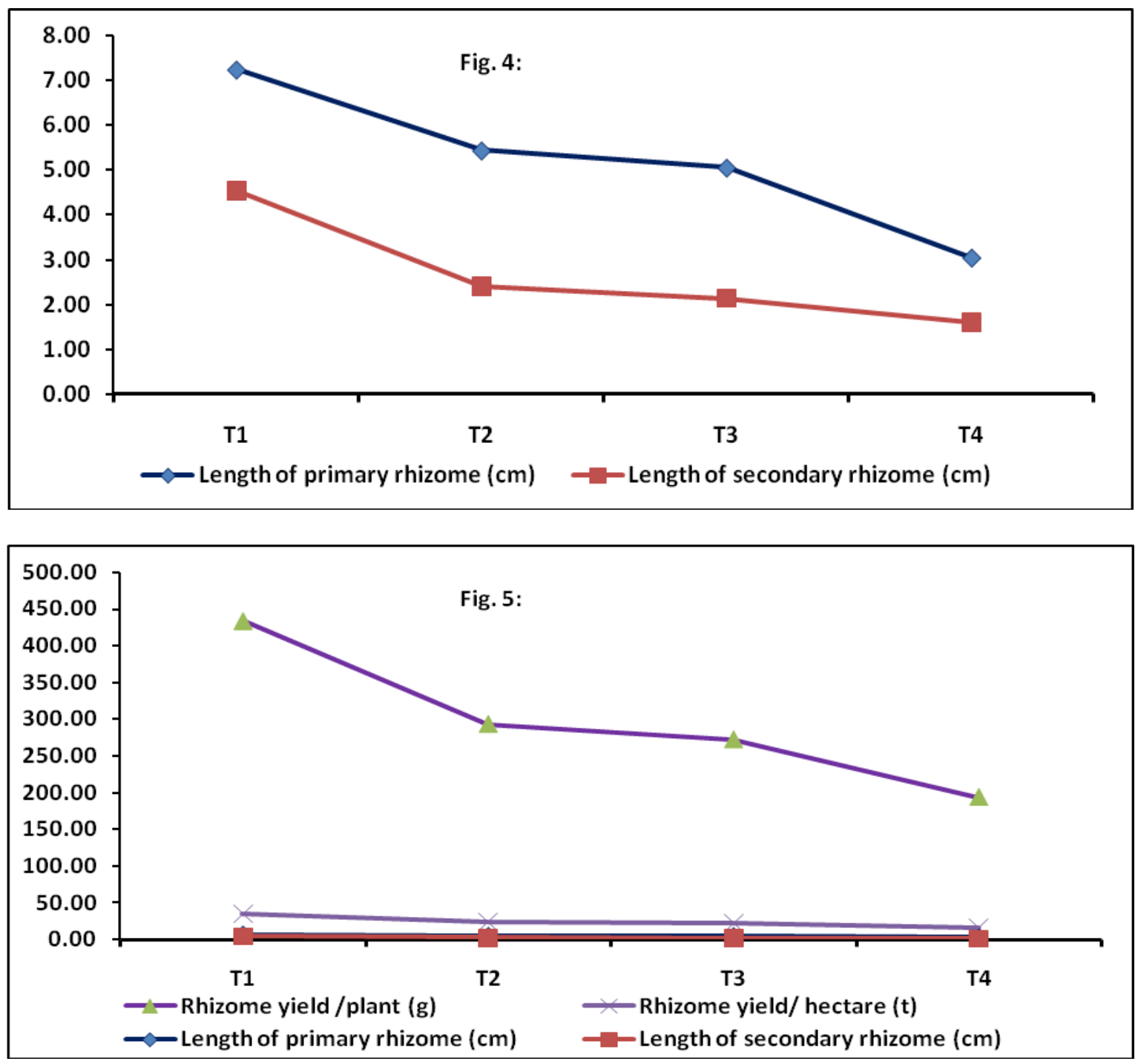

Tree leaf and paddy straw as mulch have been reported to increase the yield of ginger in Bihar (Jha et al., 1986). The higher rhizome yield with organic mulches was due to the improved growth attributes, reduced competition by weeds and improved soil conditions. The increased the yield in treatment of plastic mulch $\left(\mathrm{T}_{1}\right) 124.20 \%$ as compared to control $\left(15.49 \mathrm{t} \mathrm{ha}^{-1}\right)$. There was significant increase in yield under drip in combination with plastic mulch as compared to drip with organic mulch and drip alone without mulch.

Treatments silver color of plastic mulch materials with drip irrigation showed highest value of plant height, no. of tillers clump ${ }^{-1}$, number of leaves clump ${ }^{-1}$, days to maturity, number of primary rhizomes, length and diameter of primary rhizomes, number of secondary rhizomes, length and diameter of secondary rhizomes, rhizomes yield plant ${ }^{-1}$ and $\mathrm{ha}^{-1}$ under the treatment $\mathrm{T}_{1}$ and lowest under the treatment $\mathrm{T}_{4}$.

\section{References}

Aclan, F. and Quisumbing, E. C. 1976. Fertilizer requirement, mulch and light attenuation on the yield and quality of ginger. Philippine Agriculturist, 60: 183-91. 
Jha, R. C., Maurya, K.R. and Pandey, R. P. 1986. Influence of mulches on the yield of ginger in Bihar. Indian Cocoa Arecanut \& Spices J. 9 (4): 87-90.

Kalyankar, P.M., Takle, S.R. and Bhise, V.B 2011. Drip irrigation technique and productivity of ginger. IJMRT V.5 (2): 359-370.

Mohanty, D. C. 1977 Studies on the effect of different mulch materials on the performance of ginger in the hills of Pottangi. Orissa J. Hort. 5 (2): 11-17.

Mohanty, D. C. and Sharma, Y. N. 1978. Performance of ginger in tribal areas of
Orissa, India, as influenced by method of planting, seed treatment, manuring and mulching. J. Plantation Crops, 6: $14-16$.

Randhawa, K. S. and Nandpuri, K. S. 1969. Grow ginger in your kitchen garden. Prog. Fmg., 5: 6-7.

Reddy, Gopala., Raja, A., Tiwari, K.N. and Santosh, D.T. 2017. Yield response of Turmeric (Curcuma longa L.) under drip fertigation and plastic mulch conditions. Int. J. Purw App. Biosci. 5 (4): 1265-1269.

\section{How to cite this article:}

Mukul Kumar, Swapnil Dubey, P.K. Dwivedi, A.K. Yadav and Mohit Kumar. 2018. Influence of Different Mulch Materials on Vegetative Growth and Yield of Ginger (Zingiber officinale Rosc.) under Drip Irrigation System. Int.J.Curr.Microbiol.App.Sci. 7(02): 2546-2551. doi: https://doi.org/10.20546/ijcmas.2018.702.310 